\title{
REVIEW
}

\section{MEASURES TO PREVENT MEDICATION ERRORS IN INTENSIVE CARE UNITS}

\author{
Zuzana Plutínská ${ }^{1}$, Ilona Plevová ${ }^{2}$ \\ ${ }^{1}$ Pediatric Intensive Care Unit, Hospital Frýdek-Mistek, Czech Republic \\ ${ }^{2}$ Department of Nursing and Midwifery, Faculty of Medicine, University of Ostrava, Czech Republic
}

Received December 12, 2018; Accepted May 10, 2019. Copyright: This is an open access article distributed under the terms of the Creative Commons Attribution International License (CC BY). http://creativecommons.org/licenses/by/4.0/

\begin{abstract}
Aim: The aims were to summarize studies on the effectiveness of interventions to reduce adverse events of the medication error type and, based on the studies, to identify recommendations for preventing medication errors in intensive care units (ICUs). Design: A descriptive review. Methods: To find relevant resources, the SCOPUS and EBSCO electronic databases were searched using the following search words: prevention, medication errors, intensive care unit. Both primary and secondary studies on prevention of medication errors in ICUs were selected. Results: A total of eight primary studies and three systematic reviews were included. The studies showed considerable variability and differed in methods, numbers of monitored events or ways of data collection. The assessed interventions were pharmacist involvement, automated infusion devices, reporting medication errors, strategies to limit interruptions during drug administration, electronic health records together with support systems for clinical decision making, nurse education in drug administration and creating checklists. Conclusion: The assessment of selected studies suggests that to a certain extent, all of them showed certain medication error reduction. Due to numerous limitations, however, it is impossible to select and recommend a single approach.
\end{abstract}

Keywords: adverse event, intensive care, medication error, nursing, patient safety, prevention.

\section{Introduction}

Medication errors in intensive care units (ICUs) have far greater risk potential than those in general wards, particularly in pediatric patients. Generally, many risk factors and circumstances play a role, such as the patient's critical condition, comorbidities, physiological dysfunction, more frequent interventions or more complex drug therapy. The latter mainly includes higher amounts of drugs taken, weight-based dosing and continuous administration of drugs requiring precise dosing. Last but not least, workload and rapidly changing health conditions necessitating a rapid response are also involved. In the Czech health care system, no major changes to the drug administration process have been made over a long period of time, even though numerous strategies and technologies are used globally to reduce medication errors. One example may be a positive effect of clinical pharmacists on the incidence of incorrect doses or selection of better drug combinations. A medication error is defined as an adverse event in which a patient's/ healthcare worker's

Corresponding author: Ilona Plevová, Department of Nursing and Midwifery, Faculty of Medicine, University of Ostrava, Syllabova 19, Ostrava, Czech Republic; email: ilona.plevova@osu.cz health was or may have been threatened or damaged during healthcare provision (Machaczek, Whitfield, 2012). The Agency for Healthcare Research and Quality (AHRQ) defined a medication error as potential harm to a patient's health resulting from exposure to an inappropriate drug (AHRQ, 2018). The National Coordinating Council for Medication Error Reporting and Prevention (NCCMERP) states that medication errors are preventable and may occur at any time during drug handling (About Medication Errors). In the Czech Republic, medication errors fall under the responsibility of the State Institute for Drug Control and its surveillance activities. They are addressed by Act No. 387/2007 Coll., on pharmaceuticals, as amended, including the related Decree No. 84/2008 Coll., on good pharmaceutical practice, as amended.

According to the AHRQ, the composition of therapeutics, and thus patients' health status, continue to improve, but these benefits are also associated with higher risks. In the sense that $5 \%$ of hospitalized patients experience adverse drug events (ADEs) due to the use/application of drugs. These, however, not necessarily mean poor quality of care. Medication errors, on the other hand, refer to errors throughout the entire process of drug administration, from 
prescription to when the patient actually receives the drug. It is generally estimated that approximately half of ADEs may be prevented. In some cases, however, ADEs occur even though drugs are prescribed and administered appropriately (AHRQ, 2018).

The general risk factors for ADEs, as stated by the AHRQ, mainly include polypharmacy; older patient age associated with taking more drugs being more vulnerable to adverse effects; pediatric patients and weight-based dosing; limited computer literacy when searching information; and high-alert drugs - those potentially harming patients if used in error, having similar appearance or names but different effects (AHRQ, 2018).

The AHRQ (2018) recommends the following strategies to prevent ADEs: 1) prescribing - avoiding unnecessary drugs by adhering to conservative prescribing principles; computerized provider order entry, particularly when paired with clinical decision support systems; drug reconciliation at times of transitions in care; 2) transcribing - computerized provider order entry to eliminate handwriting errors; 3) dispensing - pharmacists overseeing the dispensing process; using tallman lettering and other strategies to minimize confusion between drugs with similar appearance or names; and 4) administration - adhering to "five rights" (i.e. the right medication, dose, time, route and patient); barcode medication administration to ensure drugs are given to the right patients; minimizing interruptions during drug preparation and administration by nurses; using smart infusion pumps for intravenous administration; patient education and revised drug labels to improve patient comprehension of administration instructions.

Drug administration is an integral part of the nursing process; a therapeutic may be applied or administered by a competent healthcare worker only when ordered by a doctor (Mikšová et al., 2006), in accordance with regulations and standards governing healthcare delivery and procedures (Vondráček, Vondráček, 2006). Richards and Edwards (2004) state that a nurse should never administer a drug without knowing its effects. Additionally, she must fully identify the patient and know their treatment plan and diagnosis. Doctor's orders must be clear and legible; in case of any doubt, a nurse should contact the doctor. Generally, the above five rights should be adhered to. Safe patient identification belongs to safety objectives as defined by the Czech Ministry of Health. A hospital must develop a regulation defining the process of patient identification; the main requirement is that there are at least two forms of patient identification (e.g. name and date of birth). A patient's identification must always be verified prior to administration of therapeutics/transfusions, laboratory tests and diagnostic or therapeutic procedures (MZČR, 2015).

At the 1996 congress of the Massachusetts Nurses Association, Cook (1999) presented the following Six Rights for Nurses Administering Medications: 1) right to a complete and clearly written order; 2) right to have the correct drug route and dose dispensed; 3 ) right to have access to information; 4) right to have policies on medication administration; 5) right to administer medications safely and to identify problems in the system; and 6) right to stop, think, and be vigilant when administering medications.

To increase patient safety and involvement in processes related to healthcare provision, the Czech Ministry of Health issued the Patient Guide in 2016. One of the chapters, Drugs in the Hospital, recommends that patients: make a list of chronically used drugs; take them to the hospital and hand them in to the hospital staff; do not use their drugs without the staff's knowledge; are aware that drugs must be administered from original packaging in their rooms; have the right to be informed about the prescribed drugs and their adverse effects; know that this information may be obtained from their attending physicians (MZČR, 2016).

\begin{abstract}
Aim
The aims were to summarize studies on the effectiveness of interventions to reduce adverse events of the medication error type and, based on the studies, to identify recommendations for preventing medication errors in ICUs.
\end{abstract}

\section{Methods}

\section{Design}

A descriptive review.

\section{Eligibility criteria}

Both primary and secondary studies published in 2008-2018 were included, with the exception of theoretical reviews. The studies had to focus on preventive strategies and measures to reduce risks associated with drug administration in ICUs. Another criterion was availability of a full text.

\section{Sources}

To find relevant resources, the SCOPUS and EBSCO electronic databases were searched.

\section{Search}

Using the PICOT format, the following search words were identified: prevention, medication errors, intensive care unit. The research question was: "Are there evidence-based recommendations or expert 
recommendations for preventing medication errors in ICUs related to nursing interventions?"

\section{Study selection}

To increase search effectiveness, synonyms were added and for all terms, asterisks or quotation marks were used (Table 1). For advanced search in electronic databases, the Boolean operators AND and OR were used.

\section{Data analysis}

The search strategy yielded a total of 189 records of which 11 studies were retrieved that were key for the review. Studies were gradually excluded using the PRISMA recommendations (Figure 1).

For the final analysis, both primary and secondary studies assessing the effect of reducing medication errors were selected. These included three systematic reviews, one study with a Plan-Do-Study-Act design, one direct observational study, two retrospective studies, three prospective studies and one quantitative survey.

Table 1 Working with search words

\begin{tabular}{lll}
\hline Search words & Synonyms & Truncation and quotations \\
\hline prevention & protection, safe, patient safety, reduction & prevent*, protect*, saf*, "patient safety", reduct* \\
medication errors & $\begin{array}{l}\text { adverse drugs event } \\
\text { critical care }\end{array}$ & $\begin{array}{l}\text { medic* error*, advers*drug* event* } \\
\text { intensive care unit }\end{array}$ \\
\hline
\end{tabular}

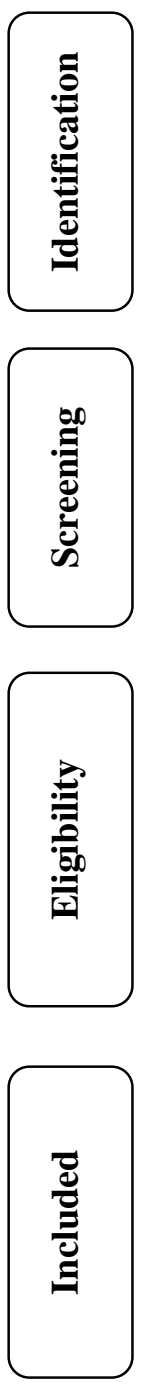

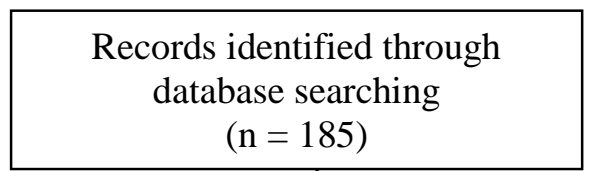

$$
(\mathrm{n}=185)
$$

Additional records identified through other sources

$$
(n=4)
$$

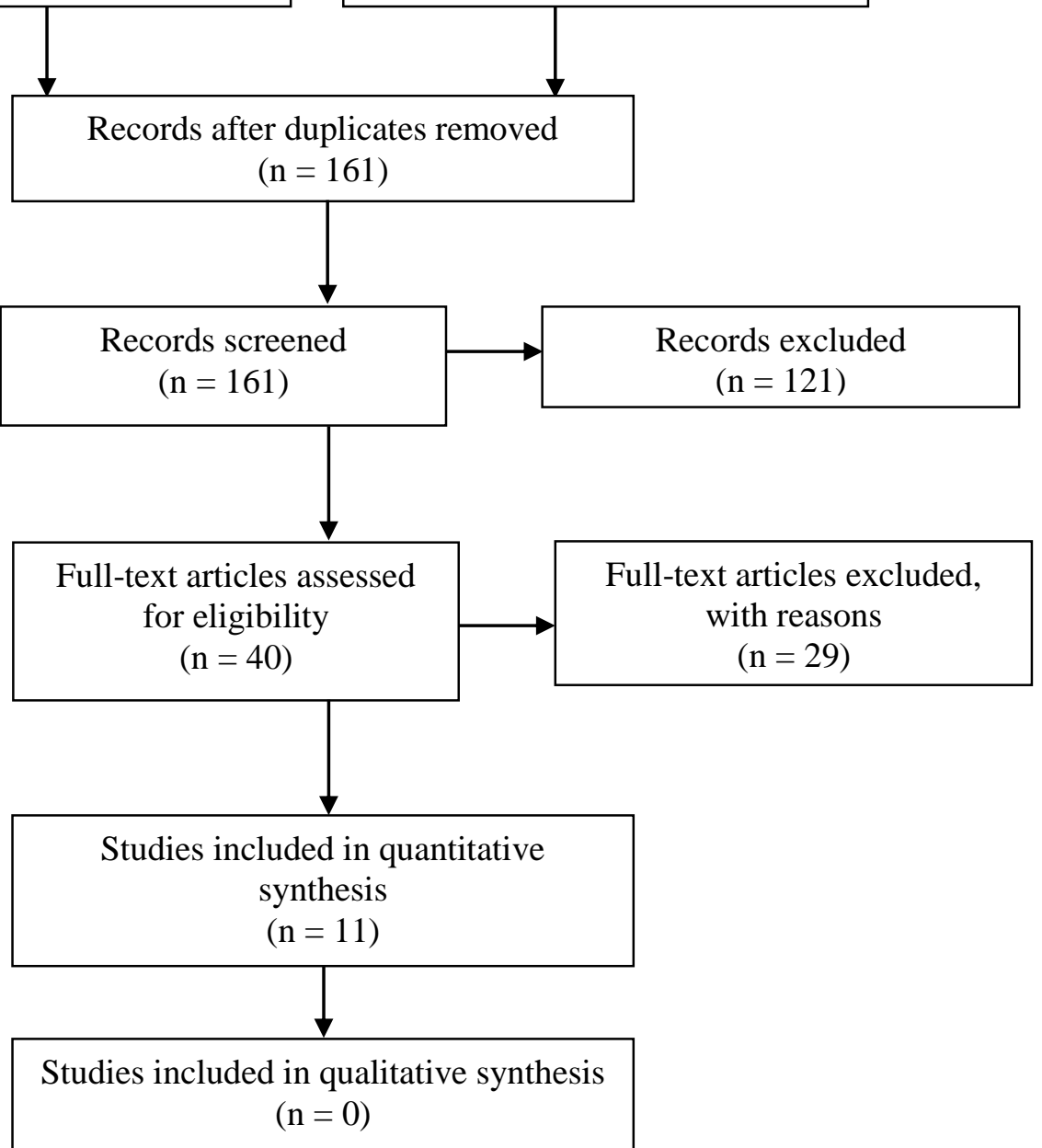

Figure 1 Flow diagram - PRISMA recommendations 


\section{Results}

The outcomes of relevant studies are presented in Table 2.

Kaushal et al. (2008) conducted a prospective cohort study in a pediatric hospital to assess medication error rates prior to and after pharmacist intervention in two ICUs. Full-time presence of a clinical pharmacist in an ICU was associated with a decrease in serious medication errors from $29 / 1000$ to $6 / 1000$ patient days $(\mathrm{p}<0.01)$. There was no significant difference in preintervention serious medication error rates between the two ICUs. On the other hand, the rate of intercepted near misses increased from $32 / 1000$ to $57 / 1000(\mathrm{p}=0.08)$ during the intervention period. Although errors were intercepted by clinical pharmacists at all stages of the medication process, the highest rate $(79 \%)$ was at a physician ordering stage. The authors concluded that the introduction of fulltime clinical pharmacists was beneficial while there was no reduction of medication errors with part-time presence.

In their retrospective study, Hennings et al. (2010) focused on automated infusion device (AID) technology used to prevent medication errors. At an academic medical center in Tucson (Arizona, USA), AID technology (smart pumps with computer processors combining drug delivery, monitoring and data management functions) was implemented in 2003 as the only type of infusion pumps, with nurses undergoing two-hour training to learn to use the technology. Only events involving high-risk drugs were assessed. According to the authors, the technology, when properly used, leads to reduction in medication error rates and is particularly useful in critically ill pediatric patients receiving high-risk drugs. Moreover, these patients are administered weight-, age- or body surface area-based dosages of drugs and solutions. The results also showed that adult patients received high-risk drugs more frequently but children were 1.68 times more likely to need pump reprogramming events.

Manias, Williams and Liew (2012) sought the effectiveness of interventions to reduce medication errors during intensive care. They identified eight types of interventions: computerized physician order entry (CPOE), changes in work schedules (CWS), intravenous systems, modules of education (ME), medication reconciliation (MR), pharmacist involvement, protocols and guidelines (PG) and support systems for clinical decision making (SSCD). Of those, only four (CWS, ME, MR and PG) demonstrated reduction of medication errors. The authors added, however, that there were concerns regarding the level of evidence and quality of studies on these interventions. The main limitations were the facts that most studies had no control groups and only assessed interventions before and after implementation.

Breeding et al. (2013) proved that the Medication Error Minimization Scheme (MEMS), their project based on multidisciplinary and multifaceted improvement of quality in an adult tertiary level ICU was able to increase the rate of reported medication errors and thus to reduce the number of errors affecting patients. According to the results, the reporting rate increased by more than $50 \%$ (from $6.2 / 1,000$ to $13.65 / 1,000$ patient days). The project also showed that although nurses agreed on the importance of reporting medication errors, nearly half of them $(43 \%$ and $66 \%$ in the pre- and post-intervention periods, respectively) stated that they had failed to report such errors, fearing that it might be personally or professionally damaging. Interestingly, respondents were encouraged to administer drugs safely but more frequently, they were pressured to be quicker rather than check things thoroughly. Nevertheless, audits of intravenous infusions revealed a reduced medication error rate.

Santesteban, Arenas and Campino (2015) conducted a systematic review to identify the most common interventions and their activities in neonatal ICUs. The most frequently reported techniques reducing medication errors, or the risk thereof, were CPOE, barcoded medication administration (BCMA), AID technology, incident reporting systems and comprehensive educational strategies. Additionally, the authors recommended implementation of multidisciplinary evidence-based measures in collaboration with pharmacists and supported changes to safety culture in healthcare facilities and medication error reporting.

A study by Durham et al. (2016) monitored the effect of a medication safety pilot program, assessed strategies promoting reporting and aimed to increase nurse sensitivity to errors and teach mindfulness. The authors suggested that interprofessional risk analysis teams were created and preventive measures recommended by them were used. The study showed that $49 \%$ of nurses agreed that their awareness of error risk increased and intended to change their practice. Moreover, the rate of reported medication errors increased.

Connor et al. (2016) aimed to assess the effectiveness of implementing a "red zone" as a strategy to prevent distraction during preparation and administration of drugs. The distraction-free practice was improved using a General Electric's model and the Six Sigma 
Table 2 Characteristics of studies included in the analysis

\begin{tabular}{|c|c|c|c|}
\hline Author (year) & Intervention/measures & Methods & Study conclusion \\
\hline $\begin{array}{l}\text { Kaushal et al. } \\
(2008)\end{array}$ & PI & prospective cohort study & $\begin{array}{l}\text { full-time PI reduces medication } \\
\text { error rates }\end{array}$ \\
\hline $\begin{array}{l}\text { Hennings et al. } \\
(2010)\end{array}$ & AID & retrospective study & $\begin{array}{l}\text { AID technology leads to } \\
\text { reductions in medication errors }\end{array}$ \\
\hline $\begin{array}{l}\text { Manias, Williams, } \\
\text { Liew (2012) }\end{array}$ & $\begin{array}{l}\text { CPOE } \\
\text { CWS } \\
\text { IS } \\
\text { ME } \\
\text { MR } \\
\text { PI } \\
\text { PG } \\
\text { SSCD* }\end{array}$ & systematic review & little evidence \\
\hline $\begin{array}{l}\text { Breeding et al. } \\
(2013)\end{array}$ & MEMS, a QI project & PDSA-based research project & $\begin{array}{l}\text { increased medication error } \\
\text { reporting rate, reduction of } \\
\text { incidents }\end{array}$ \\
\hline $\begin{array}{l}\text { Santesteban, } \\
\text { Arenas, Campino } \\
(2015)\end{array}$ & $\begin{array}{l}\text { BCMA } \\
\text { CPOE } \\
\text { AID } \\
\text { incident report systems } \\
\text { educational strategies } \\
\text { pharmacist-led educational } \\
\text { programs }\end{array}$ & systematic review & $\begin{array}{l}\text { changes to safety culture, } \\
\text { systems for reporting and } \\
\text { auditing errors, a } \\
\text { multidisciplinary evidence- } \\
\text { based approach in collaboration } \\
\text { with pharmacists }\end{array}$ \\
\hline $\begin{array}{l}\text { Durham et al. } \\
\text { (2016) }\end{array}$ & $\begin{array}{l}\text { medication error reporting } \\
\text { checklist } \\
\text { mindfulness }\end{array}$ & prospective observational study & $\begin{array}{l}\text { creating interprofessional risk } \\
\text { analysis teams and using } \\
\text { preventive strategies } \\
\text { recommended by them }\end{array}$ \\
\hline $\begin{array}{l}\text { Connor et al. } \\
(2016)\end{array}$ & $\begin{array}{l}\text { "red zone" (distraction-free } \\
\text { practice) }\end{array}$ & retrospective analysis & the "red zone" is effective \\
\hline Flynn et al. (2016) & $\begin{array}{l}\text { strategies limiting interruptions: } \\
\text { hourly patient rounds } \\
\text { protected time } \\
\text { outlining a no interruption zone } \\
\text { limiting phone calls by triage } \\
\text { visible wear } \\
\text { patient/family education } \\
\text { materials }\end{array}$ & $\begin{array}{l}\text { direct observational study with } \\
\text { a control group }\end{array}$ & $\begin{array}{l}\text { strategies limiting interruptions } \\
\text { improve patient safety but their } \\
\text { effect on medication errors is } \\
\text { unclear }\end{array}$ \\
\hline $\begin{array}{l}\text { Di Simone et al. } \\
\text { (2016) }\end{array}$ & nurses' knowledge & quantitative survey & pharmacological knowledge \\
\hline Liao et al. (2017) & $\begin{array}{l}\text { EHR } \\
\text { CPOE } \\
\text { BCMA }\end{array}$ & prospective observational study & $\begin{array}{l}\text { reduction in medication error } \\
\text { after implementation of EHR } \\
\text { together with CPOE and } \\
\text { BCMA }\end{array}$ \\
\hline $\begin{array}{l}\text { Nguyen, Mosel, } \\
\text { Grzeskowiak } \\
(2018)\end{array}$ & $\begin{array}{l}\text { technology, } \\
\text { organizational, guidelines, } \\
\text { policies } \\
\text { personnel (education) } \\
\text { pharmacy services } \\
\text { risk analysis } \\
\text { combinations of the above }\end{array}$ & systematic review & $\begin{array}{l}\text { no single intervention to reduce } \\
\text { medication errors in neonatal } \\
\text { care was clearly superior; the } \\
\text { use of technology was a } \\
\text { priority }\end{array}$ \\
\hline
\end{tabular}

AID - automated infusion device; CPOE - computerized physician order entry; CWS - changes in work schedules; IS - intravenous systems; ME- modules of education; MR - medication reconciliation; PI- pharmacist intervention/involvement; PG - protocols and guidelines; SSCD - support systems for clinical decision-making; EHR - electronic health records; BCMA - bar-coded medication administration; MEMS - Medication Error Minimization Scheme; QI quality improvement; PDSA - Plan-Do-Study-Act 
tool involving a five-step approach: define, measure, analyze, improve and control. The General Electric's model was used to accelerate changes in each of the five steps. A badge was designed to be worn and visible, a red zone decal was placed on the floor, and staff members, patients and families were informed about the strategy and asked to adhere to the rules. This resulted in a $79.2 \%$ reduction in medication errors. A rather important limitation of the study was that during the strategy assessment, a medication barcode scanning process was introduced in the hospital, potentially distorting the results.

A direct observational prospective study by Flynn et al. (2016) aimed to assess the effectiveness of strategies to limit interruptions during medical administration in ICUs. The implemented interventions whose effectiveness was evaluated were regular patient assessment; protected time (no interruption drug administration times: $5 \mathrm{am}-7 \mathrm{am}, 8$ am - 10 am, 8 pm - $10 \mathrm{pm}$ ); hourly rounds (regular patient assessment, e.g. every two hours); nurses wearing a yellow safety sash to signify that they are not to be disturbed; establishment of no interruption zones; limitation of phone calls (triage of phone calls); distribution of patient/family education materials. Direct observations were retrospectively analyzed from adapted standardized records (Medication Administration Accuracy Observation Code Sheet; Medication Administration Accuracy Record Review Worksheet) developed by the California Nursing Outcomes Coalition. The results showed that the most common sources of interruptions were patient-related, phone calls, face-to-face interaction and unavailability of resources during preparation/administration (sufficient fluids to facilitate drug swallowing). According to the authors, limiting nurse interruptions improves drug safety but the effect on medication error rates is unclear.

Di Simone et al. (2016) reported elements of nurses' knowledge, training, behavior and attitude potentially preventing medication errors in ICUs during administration of intravenous drugs. They concluded that the prerequisite for proper administration of drugs and evaluation of their effects is pharmacological knowledge.

Due to doubts about the effectiveness of electronic health records (EHR) in preventing medication errors, Liao et al. (2017) studied interventions including CPOE and BCMA. After EHR implementation, the types and severity of medication errors changed. More specifically, medication administration record discrepancies, incomplete orders and missed doses changed to missed doses and wrong time of administration in the postimplementation period.
Moreover, the rate of near-misses increased. The authors claim that in the short-term, EHR implementation did not lead to reduction in medication errors. There was a significant decrease after as long as two years. The authors also explain that unawareness of these technologies could initially cause new adverse events.

Nguyen, Mosel and Grzeskowiak (2018) conducted a systematic review to study the effectiveness of interventions to reduce medication errors in neonatal care. In the identified studies, interventions were classified into five themes: technology, organizational, personnel, pharmacy, hazard and risk analysis. A qualitative synthesis of comparative studies showed that the greatest median reduction $(73 \%)$ in overall medication errors was seen when technology-based interventions were used. The authors promote technologies such as CPOE with automated dose checking, E-calculators, AID, BCMA, preparation of prediluted drugs for administration, etc.

\section{Discussion}

A possible solution to reduce medication errors is to employ full-time pharmacists, particularly in pediatric ICUs (Kaushal et al., 2008). For successful involvement of pharmacists and other professionals in addressing ADEs, it is necessary to implement an accessible system for reporting adverse events so that staff members do not face barriers that discourage them from reporting such events. It is also important to create an environment that supports error reporting and repeated meetings allowing bilateral exchange of information and experiences (Breeding et al., 2013; Durham et al., 2016). One of the reasons for errors to happen may be interruptions during drug preparation and administration. This, however, was not confirmed by an identified study (Flynn et al., 2016). Yet this strategy is perceived as suitable with regard to patient safety and is also recommended by the AHRQ (AHRQ, 2018). The importance of this aspect was also shown in a survey by Di Simone et al. (2016). Respondents perceived training of new colleagues as a high-risk area. These situations undoubtedly place high demands on attention. Distraction-free practices were also recommended by Connor et al. (2016) who used various methods to significantly reduce medication errors by $79.2 \%(p=0.00184)$. However, there were certain limitations: the results were based on self-reporting of errors and a BCMA system was introduced at the same time.

The AID technology is mainly recommended in pediatric units where patients are at a higher risk of inadequately ordered/set care (Hennings et al., 2010). Nicholas and Agius (2005) explain that smart pumps 
may warn nurses of errors in the process (not the right patient, amount, drug, time or route). These pumps have their own libraries of drugs with protocols in software to compare the set parameters with the limits. Other pump parameters may be set such as clinical condition, age or drug compatibility information. The authors conclude that administration of IV drugs is a complex issue and errors may be reduced by using AID and other risk reduction strategies such as CPOE and BCMA and improving nurse education in drug administration.

Using EHR, CPOE and BMCA may reduce medication errors by as much as $24 \%(\mathrm{p}=0.0008)$ over a long period of time (Liao et al., 2017). According to Cima and Clarke (2012) and Plischke (2015), each healthcare provider should establish a multidisciplinary team for drug management (physicians, IT specialists, pharmacists, specialist nurses) and introduce BCMA to try to prevent human errors. This strategy is also supported by the European Association of Hospital Pharmacists claiming that errors may be reduced by approximately one third. In the Czech Republic, the system is used, for example, when cytostatic drugs are administered in the Masaryk Memorial Cancer Institute in Brno. It is based on central preparation and interlinked processes from prescription to administration. Prior to administration, the nurse clearly identifies the centrally prepared cytostatic drug and the patient by reading a barcode, including the technique to be used and her own identity (Oldřichová, 2010). Yet BCMA is not a one-size-fits-all solution as it is always dependent on the proportions of particular errors. The technology does reduce certain types of errors but also introduces novel errors in the form of work-arounds (Keers et al., 2013).

A systematic review by Santesteban, Arenas and Campino (2015) showed that all interventions (CPOE, BCMA, AID, medication error reporting, education) had reduced the incidence or risk of medication errors in neonatal care and recommended changes in the culture of error reporting and auditing as well as implementation of any evidence-based interventions in collaboration with pharmacists. To a certain extent, however, this was not confirmed by other systematic reviews which showed a reduced incidence of errors but their authors had doubts about the quality of such evidence. A review by Nguyen, Mosel and Grzeskowiak (2018) found the greatest median reduction in medication errors $(73 \%)$ with the use of technologies (e.g. CPOE, BCMA, AID and E-calculators). Other strategies such as organizational changes, risk analysis, pharmacy services were also associated with error reduction but the median was lower $(50-60 \%)$. The authors recommended further research to evaluate the cost-effectiveness of various interventions. According to Manias, Williams and Liew (2012), medication errors in adult intensive care were reduced following implementation of education strategies, promotion of medication error reporting, changes in work schedules and the use of protocols and guidelines. Similar results were shown by another study focusing not only on ICUs but inpatient settings in general. In their systematic review and metaanalysis, Berdot et al. (2016) found that high-quality studies to evaluate the effectiveness of interventions reducing medication errors were lacking. The authors identified a total of 26 studies evaluating such interventions based on direct observations, of which only seven met the criteria for inclusion in the analysis. Those comprised five randomized controlled trials and two non-randomized controlled studies. Three of them focused on CPOE or automated dispensing systems; four studies were concerned with nurse education. However, all the studies were susceptible to bias. There were no differences in overall administration error rates between the intervention and control groups. Potential biases were likely to be greater for non-randomized studies. According to the authors, results from before and after studies should be interpreted with caution (Berdot et al., 2016).

All the above strategies, however, may not lead to effects they actually offer. Additional literature search for resources in Czech language yielded a 2015 diploma thesis called Identification of medication errors by nurses during simulated scenarios by Kelblová (2015). A qualitative analysis of interviews with nurses $(n=13)$ selected at a single ICU showed that although they did not know the exact definition of medication errors their awareness of those was relatively good. In simulated scenarios, none of the nurses was able to detect all errors. One example of a rarely identified error was wrongly prescribed insulin (a lack of detailed descriptions of units, time and route of administration); the least frequently detected error was wrong prescription of infusions. By contrast, incomplete opioid orders (no route of administration stated) were most commonly recognized. The author concluded that the interviewed nurses were aware of medication errors and their ability to detect them during simulated scenarios was related to the number of years of experience and level of education (Kelblová, 2015).

\section{Limitations of study}

The main limitations of the search strategy were the availability of full texts and choosing English as the only possible language. Another limitation may be looking for studies conducted in ICUs only. Surely 
a considerable proportion of studies were performed in general wards so other methods could have been found, potentially applicable in the intensive care setting.

\section{Conclusion}

The assessment of selected studies suggests that to a certain extent, all of them showed certain medication error reduction. Due to numerous limitations of either the selected studies or our search strategy, however, it is impossible to select and recommend a single approach. Such selection mainly depends on healthcare providers' financial resources and types of medication errors that occur.

Therefore, the selected recommendations for practice are mainly based on interventions recommended by the AHRQ, with regard to conclusions of the identified studies.

Although the evidence failed to provide a particular instrument or method, it may be assumed that any combination of technologies together with education and a good system for reporting medication errors seem to be a good strategy. According to the AHRQ, during prescription certain principles should be adhered to such as avoiding unnecessary medications, using the CPOE technology and medication reconciliation at times of patient transition. For transcription, they recommend computerized/printed orders, clinical pharmacists overseeing drug dispensation and the use of tallman lettering. In the process of administration itself, the "five rights" should be adhered to, the BCMA and AID technologies should be used, interruptions minimized and patients educated (AHRQ, 2018).

Based on results of the studies, we may recommend electronic health records together with clinical decision support systems, zero tolerance to handwritten orders, with the exception of situations requiring immediate help, a policy of not interrupting nurses during drug administration, implementation of AID technology, particularly in pediatric ICUs, better educational strategies to promote knowledge about drugs administered and awareness of adverse events occurring in particular departments (drugs suitable for nasogastric tubes, high-risk drugs, intravenous drugs, discussion on adverse drug reactions that have occurred, including near-errors), creating checklists tailor-made to suit the needs of departments and, last but not least, involvement of pharmacists in medication processes.

\section{Ethical aspects and conflict of interest}

The authors solemnly declare that the manuscript has not yet been published or submitted for publication by another journal, they have no conflict of interest regarding the topic, creation and publication of this article and that it has not been supported by a commercial organization.

\section{Author contributions}

Conception and design (IP, ZP), data analysis and interpretation (ZP), manuscript draft (IP, ZP), critical revision of the manuscript (IP, ZP), final approval of the manuscript (IP).

\section{References}

About Medication Errors. NCCMERP (C) 2018 [cited 2017 Dec 21]. Available from: http://www.nccmerp.org/aboutmedication-errors/

AHRQ. Medication Errors. Last revision 2017 Jun 1 [cited 2017 Dec 21]. Available from: http://psnet.ahrq.gov/primer.aspx?primerID=23

Berdot S, Roudot M, Schramm C, Katsahian S, Durieux P, Sabatier B. Interventions to reduce nurses' medication administration errors in inpatient settings: A systematic review and meta-analysis. International Journal of Nursing Studies. 2016;53:342-350.

Breeding J, Welch S, Whittam S, Buscher H, Burrows F, Frost C, Jonkman M, Mathews N, Wong KS, Wong A. Medication Error Minimization Scheme (MEMS) in an adult tertiary intensive care unit (ICU) 2009-2011. Australian Critical Care. 2013;26(2):58-75.

Cima LE, Clarke S. The nurse's role in medication safety. 2nd ed. Illinois: Oakbrook Terrace; 2012.

Connor JA, Ahern JP, Cuccovia B, Porter CL, Arnold A, Dionne RE, Hickey PA. Implementing a distraction-free practice with the red zone medication safety initiative. Dimensions of Critical Care Nursing. 2016;35(3):116-124.

Cook MC. Nurses' six rights for safe medication administration. 1999 [cited 2018 Nov 27]. MNA (C) 2017. Available from: http://www.massnurses.org/nursingresources/nursing-practice/articles/six-rights

Di Simone E, Tartaglini D, Fiorini S, Petriglieri S, Plocco C, Di Muzio M. Medication errors in intensive care units: nurses' training needs. Emergency Nurse. 2016;24(4):24-29.

Durham ML, Suhayda R, Normand P, Jankiewicz A, Fogg L. Reducing medication administration errors in acute and critical care. JONA: The Journal of Nursing Administration. 2016;46(2):75-81.

Flynn F, Evanish JQ, Fernald JM, Hutchinson DE, Lefaiver C. Progressive care nurses improving patient safety by limiting interruptions during medication administration. Critical Care Nurse. 2016;36(4):19-35.

Hennings S, Romero A, Erstad BL, Franke H, Theodorou AA. A comparison of automated infusion device technology to prevent medication errors in pediatric and adult intensive care unit patients. Hospital Pharmacy. 2010;45(6):464-471.

Kaushal R, Bates DW, Abramson EL, Soukup JR, Goldmann DA. Unit-based clinical pharmacists' prevention of serious medication errors in pediatric inpatients. American Journal of Health-System Pharmacy. 2008;65(13):1254-1260. 
Keers NR, Williams SD, Cooke J, Ashcroft DM. Causes of medication administration errors in hospitals: a systematic review of quantitative and qualitative evidence. Drug Safety. 2013;36(11):1045-1067.

Kelblová K. Identifikace medikačního pochybení sestrou $v$ rámci nácviku modelových situací. 87 p. Diplomová práce. Vedoucí diplomové práce Iva Brabcová. České Budějovice: Jihočeská univerzita v Českých Budějovicích, Zdravotně sociální fakulta, Katedra ošetřovatelství a porodní asistence; 2015. (in Czech)

Liao TV, Rabinovich M, Abraham P, Perez S, DiPlotti C, Han JE, Martin GS, Honig E. Evaluation of medication errors with implementation of electronic health record technology in the medical intensive care unit. Open Access Journal of Clinical Trials. 2017;9:31-40.

Machaczek KK, Whitfield M. Doporučené postupy v oblasti prevence a identifikace nežádoucích událostí v nemocnicich v České republice. 2012, 69 p. [cited 2017 Oct 1]. Available from: http://www.projecthope.cz/uploads/nil_nocere/PARTS1-7-pouze\%20postupy-Aug15,2012.pdf (in Czech)

Manias E, Williams A, Liew D. Interventions to reduce medication errors in adult intensive care: a systematic review. British Journal of Clinical Pharmacology. 2012;74(3):411423.

Mikšová Z, Froňková M, Hernová R, Zajičcková M. Kapitoly $z$ ošetřovatelské péče 1. Praha: Grada Publishing; 2006. (in Czech)

MZČR. Resortni bezpečností cíle. 2015. MZČR (C) 2010. Last revison 2018 Jan 29 [cited 2018 Nov 27]. Available from: http://www.mzcr.cz/KvalitaABezpeci/obsah/resortnibezpecnostni-cile-_2922_29.html (in Czech)

MZČR. Rádce pacienta. 2016. MZČR (C) 2010. Last revision 2016 Mar 2 [cited 2017 Dec 18]. Available from: http://www.mzcr.cz/KvalitaABezpeci/obsah/radcepacienta_2898_29.html (in Czech)
Nguyen MR, Mosel C, Grzeskowiak LE. Interventions to reduce medication errors in neonatal care: a systematic review. Therapeutic Advances in Drug Safety. 2018;9(2):123-155.

Nicholas PK, Agius CR. Toward safer IV medication administration: the narrow safety margins of many IV medications make this route particularly dangerous. American Journal of Nursing. 2005;105(3 Suppl):25-30.

Oldřichová L. Kde jsou lidé, tam vznikají chyby [online]. Medical tribune. 2010;6(19). [cited 2018 May 23]. Available from: http://www.tribune.cz/clanek/19088-kde-jsou-lide-tamvznikaji-chyby (in Czech)

Plischke S. V elektronizaci, a tedy i bezpečnosti, medikačního procesu za Evropou zaostáváme. In. ISSS 2015: 18. ročník konference ISSS, Hradec Králové 13.-14. dubna 2015: sbornik př́spěvků konference [online]. (C) 2015 Triada, spol. s.r.o. [cited 2017 May 23]. Available from: https://www.isss.cz/archiv/2015/download/isss2015.pdf (in Czech)

Richards A, Edwards S. Repetitorium pro zdravotni sestry. Praha: Grada Publishing, a.s.; 2004. (in Czech)

Santesteban E, Arenas S, Campino A. Medication errors in neonatal care: a systematic review of types of errors and effectiveness of preventive strategies. Journal of Neonatal Nursing. 2015;21(5):200-208.

Vondráček L, Vondráček J. Pochybeni a sankce při poskytování ošetřovatelské péče II. Praha: Grada Publishing, a.s.; 2006. (in Czech)

Vyhláška č. 84 ze dne 26. února 2008 o správné lékárenské praxi, bližších podmínkách zacházení s léčivy v lékárnách, zdravotnických zařízeních a u dalších provozovatelů a zařízení vydávajících léčivé príípravky. In. Sbirka zákonů, Česká republika. 2008, částka 25. (in Czech)

Zákon č. 378 ze dne 6. prosince 2007 o léčivech. In. Sbirka zákonů České republiky. (in Czech) 